\title{
Monitoring and Assessment on the UNESCO Endangered Heritage Sites using Space Technology- A Case Study on East Rennell, Solomon Islands
}

\section{Sijia Huo}

1.International Centre on Space Technologies for Natural and Cultural Heritage,The Aerospace Information Research Institute,Chinese Academy of Sciences; 2.University of Chinese Academy of Sciences

\section{Wang Mengmeng}

China University of Geosciences

\section{GuoLong Chen ( $\nabla$ chenguolong_cgl@163.com )}

Aerospace Information Research Institute,Chinese Academy of Science https://orcid.org/0000-0001-

9111-0552

\section{Shu Huiqin}

1.International Centre on Space Technologies for Natural and Cultural Heritage, The Aerospace Information Research Institute, Chinese Academy of Sciences; 2.University of Chinese Academy of Sciences

\section{RuiXia Yang}

1.International Centre on Space Technologies for Natural and Cultural Heritage, The Aerospace Information Research Institute, Chinese Academy of Sciences;2.University of Chinese Academy of Sciences

\section{Research article}

Keywords: World Heritage, East Rennell, Solomon Island, Vegetation Change, Multi-source Remote Sensing Data

Posted Date: May 11th, 2021

DOI: https://doi.org/10.21203/rs.3.rs-467580/v1

License: (c) (1) This work is licensed under a Creative Commons Attribution 4.0 International License. Read Full License 


\section{Monitoring and Assessment on the UNESCO}

2 Endangered Heritage Sites using Space

3 Technology-A Case Study on East Rennell,

4 Solomon Islands

5 Sijia Huo ${ }^{1,2}$, Mengmeng Wang ${ }^{3}$, Guolong Chen ${ }^{1,2^{*}}$, Huiqin Shu ${ }^{1,2}$, Ruixia Yang ${ }^{1,2}$,

6 Abstract: Space technology is an effective approach to monitor the status of World

7 Natural Heritage sites. East Rennell Island has been inscribed on the List of World

8 Heritage in danger since 2013. The site includes approximately 37,000 hectare (ha) and

9 a marine area extending three nautical miles to sea. Deforestation and natural

10 disasters have become the increasing factors threatening its sustainable development.

11 Based on the analyses of multi-source long-time series remote sensing data like MODIS

12 and Worldview data, the forest cover change and its future trends in Rennell Island

13 from 2000 to 2020 have been mapped and assessed using Sen+Mann-Kendall and

14 Hurst index models. A land cover classification system derived from the high-resolution

15 Worldview images was developed as a baseline product for monitoring and analyzing

16 future forest cover changes in East Rennell Island. Our results show that: (1) Area of

17 the vegetation degradation is basically same as that of vegetation improvement from

182000 to 2020. (2) The trend of forest cover change is weak in continuity, and significant

19 improvements in damaged vegetation can be implemented but it needs enough

20 protection measures and financial input. (3) This heritage site has a strong ability to

21 regenerate vegetation, and it is recommended to restrict the human activities like the

22 mining, logging, and road construction, which could greatly disturb the unique

\footnotetext{
*Correspondence:: chenguolong_cgl@163.com
} 
ecosystem.

Key Words: World Heritage, East Rennell, Solomon Island, Vegetation Change, Multisource Remote Sensing Data

\section{Introduction}

Space technologies represented by $3 \mathrm{~S}$ technology has the characteristics of realtime and high-precision positioning, dynamic multi-temporal resolution data acquisition, intelligent and efficient data management, and analysis for the world heritage sites ${ }^{[1]}[1-3]$. It is urgent to monitor them continuously and put forward protective measures. The UNESCO World Heritage Center supervises and helps the Solomon Islands' government improve the protection and management of East Rennell World Heritage Site by providing funding and technical coordination, including entrusting. HIST (The International Centre on Space Technologies for Natural and Cultural Heritage, is a Category-II center under auspices of UNESCO) to facilitate the monitoring of changes in the forest cover of Rennell Island. HIST is the first UNESCO center to apply space technologies to monitor and preserve natural and cultural heritage sites. The center is hosted by the Aerospace Information Research Institute of the Chinese Academy of Sciences. Cultural and natural heritages with high universal value are threatened by natural forces and human actions, especially those included in the List of World Heritage in Danger[4]. HIST has employed the space technology to monitor these changes over Rennell Island using the high-resolution data of 2015 as a benchmark for evaluating Rennell Island's future changes[5]. This paper presents a study on forest vegetation cover changes from 2000 to 2020 in one of the world's 
endangered heritage sites - the East Rennell Island in the Solomon Islands - as an example and establishes a land classification system to monitor and predict the future changes. Coverage changes are expected to provide scientific support for the restoration and protection of the world's endangered heritage sites.

The Solomon Islands are in Melanesia, in the South Pacific Ocean, east of Papua New Guinea. It is classified as a Least Developed Country (LDC) \& a Small Island Developing State (SIDS).

East Rennell makes up the southern third of Rennell Island, the southernmost island in the Solomon Island group in the western Pacific (Fig.1). It has been designated on the World Heritage List in 1998[6], and was included on the danger list since 2013 due to logging that is adversely affecting the heritage site's ecosystem. The World Heritage Committee determined that logging is threatening East Rennell's outstanding universal value and has asked the national authorities to provide an impact assessment study of the logging, although it is taking place outside the core area of heritage site. 


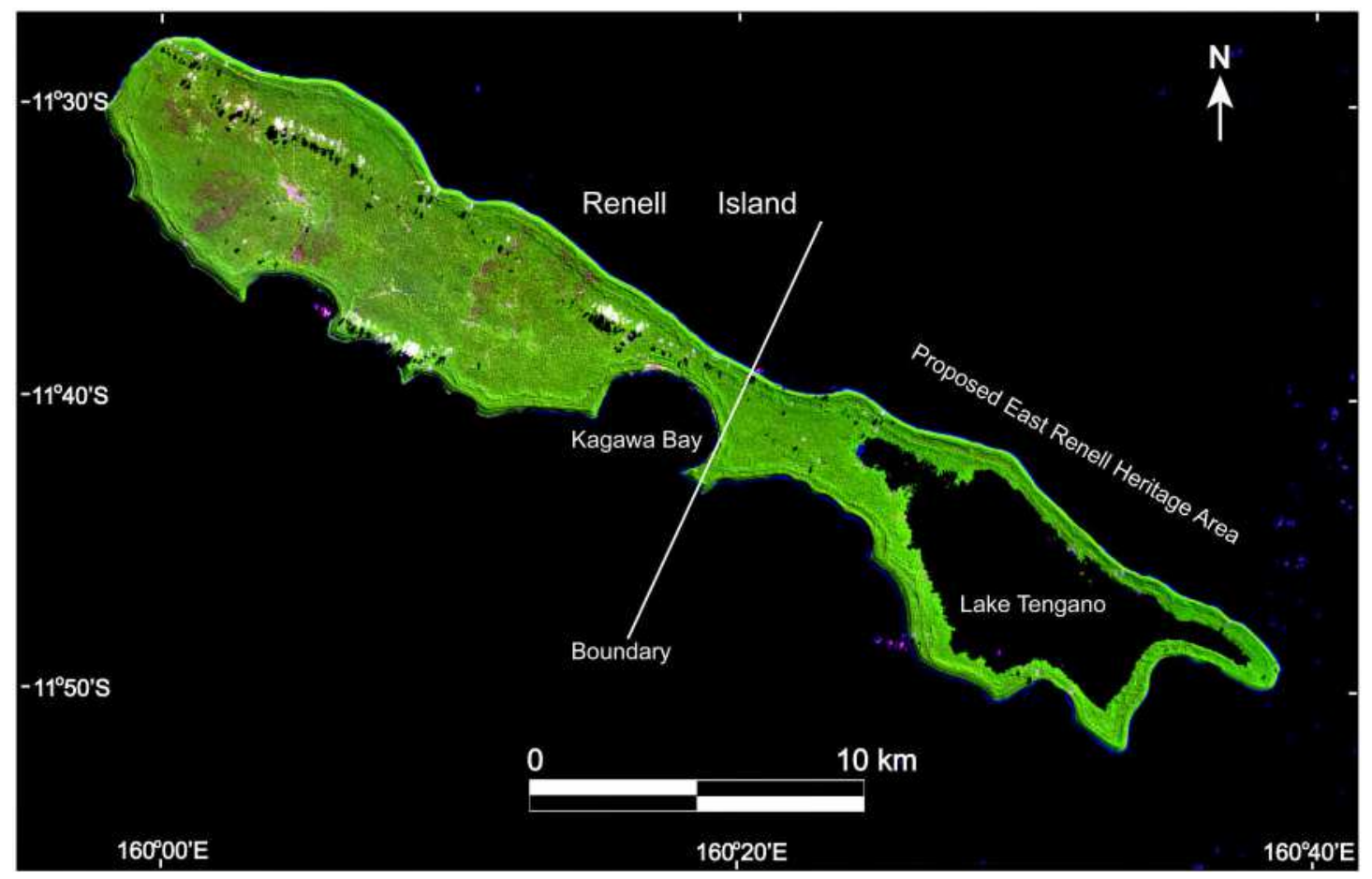

Figure 1 Landsat 8 image of Rennell Island showing the vegetation coverage of East Rennell heritage site on June 07, 2016

East Rennell demonstrates significant ongoing ecological and biological processes and is an important site for Island biogeography science. The property is an important stepping stone in the migration and evolution of species in the western Pacific for speciation processes, especially for avifauna. The unmodified forest vegetation contains floral elements from the more impoverished Pacific Islands to the east and the much richer Melanesian flora to the west. For its size, Rennell Island has a high number of endemic species, particularly among its avifauna, and harbors ten endemic plant species[7].

The wildlife includes 11 species of bat (one endemic) and 43 species of breeding land and water birds (four species and nine endemic subspecies, respectively). The invertebrate life is also rich with 27 species of land snail (seven endemics) and 
approximately 730 insect species, many of which are endemic. The flora of Lake Tengano is dominated by more than 300 species of diatoms and algae, some of which are endemic. There is also an endemic sea snake in the lake [8].

\section{Data and Methods}

Data on the relative distribution of endemic and native species of Rennell Island are poor or non-existing, making systematic assessments of threats and their impacts is difficult. Risk monitoring and preventive diagnosis of threats to heritage sites in any given ecosystem are complex and challenging tasks[9]. Taking advantage of long-term Earth satellite observations, we use remote sensing data to monitor the forest cover change and classify the land cover that is an effective assessment tool to protect Rennell Island.

\subsection{Data}

Rennell Island, as a tropical island, is often obscured by dense clouds, which have a significant impact on vegetation monitoring and land cover classification from optical remote sensing data. By collecting and compiling multi-source remote sensing data and selecting high quality data without or with few clouds, we obtained 432 scenes of Moderate-resolution Imaging Spectroradiometer(MODIS) generated Normalized Difference Vegetation Index (NDVI) 16 days synthetic data (250 m ground-resolution), 7 scenes of Landsat 7/8 data (30 m ground-resolution), 20 scenes of Worldview data, and 7 scenes of Hansen data (Table 1) between 2000 to 2020. 
Table 1 Satellite remote sensing data covering the Rennell Island

\begin{tabular}{|l|c|c|l|}
\hline \multicolumn{1}{|c|}{$\begin{array}{c}\text { Data } \\
\text { Sources }\end{array}$} & Resolution & $\begin{array}{c}\text { Data } \\
\text { Size }\end{array}$ & \multicolumn{1}{|c|}{ Acquisition Time } \\
\hline \multicolumn{1}{|c|}{ MODIS } & $250 \mathrm{~m}$ & 432 & $2000 \backslash 01 \backslash 01-2020 \backslash 08 \backslash 27$ \\
\hline Landsat 7 & $30 \mathrm{~m} / 15 \mathrm{~m}$ & 2 & $2012 \backslash 06 \backslash 05,2013 \backslash 04 \backslash 21$ \\
\hline Landsat 8 & $30 \mathrm{~m} / 15 \mathrm{~m}$ & 5 & $\begin{array}{l}2014 \backslash 03 \backslash 15,2015 \backslash 08 \backslash 09,2016 \backslash 06 \backslash 07,2016 \backslash 06 \backslash 24, \\
2017 \backslash 03 \backslash 07,2018 \backslash 06 \backslash 14\end{array}$ \\
\hline Worldview & $2 \mathrm{~m} / 0.5 \mathrm{~m}$ & 20 & $2014 \backslash 03 \backslash 19-2015 \backslash 10 \backslash 03$ \\
\hline Hansen & $30 \mathrm{~m}$ & 7 & $2012-2018$ \\
\hline
\end{tabular}

96

97

\subsection{Methods}

Before data analysis, the original data is preprocessed (Fig. 2).

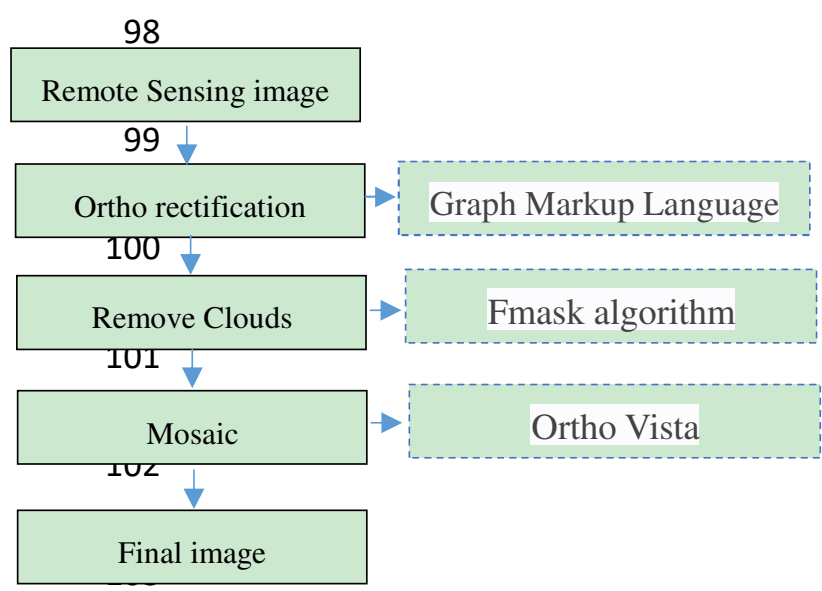

104

105

106 NDVI is the most widely used vegetation index, reflecting the typical spectral

107 characteristics of vegetation. There is a significant linear correlation between vegetation

108 coverage and NDVI [10]. In applying the dimidiate pixel model, due to the complexity

109 of land surface, a single selection of two extreme points of NDVI at a global scale will

110 cause great uncertainty in the estimation of vegetation coverage [11]. The maximum

111 and minimum values of NDVI data obtained from remote sensing images of the study

112 area are selected as the NDVI values of pure vegetation and bare soil[12].

Figure 2 Flow chart for processing of the preprocessed data
Scale: $30 \mathrm{~m}$ and $50 \mathrm{~m}$

Shape: 01.m Compactness: $0.5 \mathrm{~m}$

\section{eCognition NDVI and texture}

Visual Interpretation

Classification Map

Based on Automatic Classification and visual interpretation 


$$
\begin{gathered}
N D V I=\frac{\text { DNnir-DNred }}{\text { DNnir+DNred }}(1) \\
\mathrm{P}=\left(\mathrm{NDVI}_{-} \mathrm{NDVI}_{\min }\right) /\left(\mathrm{NDVI}_{\max }-\mathrm{NDVI}_{\min }\right)
\end{gathered}
$$

Where NDVI is the normalized vegetation index; DNnir is near-infrared reflectance; DNred is red reflectance; $\mathrm{P}$ is vegetation coverage; $\mathrm{NDVI}_{\max }$ is NDVI value of pure vegetation in the study area; $\mathrm{NDVI}_{\min }$ is NDVI value of bare soil in the study area.

We referred to the vegetation coverage division method, the vegetation coverage (C) in the study area was divided into five grades, as shown in Table 2. Despite concerns about work on logging and mining concessions, raw forest coverage remained high across the Island, especially in East Rennell Island, which maintained the highest record.

Table 2 Division table of vegetation coverage

\begin{tabular}{|c|c|}
\hline $\mathrm{P} \leq 0.2$ & Lower vegetation coverage \\
\hline $0.2<\mathrm{P} \leq 0.4$ & Low vegetation coverage \\
\hline $0.4<\mathrm{P} \leq 0.6$ & Moderate vegetation coverage \\
\hline $0.6<\mathrm{P} \leq 0.8$ & High vegetation coverage \\
\hline $\mathrm{P}>0.8$ & Higher vegetation coverage \\
\hline
\end{tabular}
correlation coefficient analysis in that it does not need data to satisfy normal distribution

127 and has small errors. It can effectively reflect the long-time series dynamic 128 characteristics of vegetation[13]. It has a significant effect on studying climate change, hydrology, and meteorology. NDVI sequence images between 2000 to 2020 were 
selected for analysis.

$$
\text { Sen-Trend Calculation Formula: }
$$

$$
\beta=M e d i a n\left(x_{j}-x_{i} / j-i\right), \forall j>i
$$

The positive and negative of $\beta$ reflects the upward and downward trend, where $\beta>0$ indicates an increasing trend of NDVI, $\beta=0$ indicates the basic unchanged trend of NDVI, $\beta<0$ indicates ta decreasing trend of NDVI.

The significance test calculation procedure for the Mann-Kendall method is as follows:

For time series T, the statistic S of the Mann-Kendall method is calculated by the formula (4):

$$
\begin{aligned}
& S=\sum_{i=1}^{n-1} \sum_{j=i+1}^{n} \operatorname{sgn}\left(x_{j}-x_{i}\right) \\
& \operatorname{sgn}\left(x_{i}-x_{j}\right)= \begin{cases}+1, & x_{j}-x_{i}>0 \\
0, & x_{j}-x_{i}=0 \\
-1, & x_{j}-x_{i}>0\end{cases}
\end{aligned}
$$

Where $x_{j}$ is the $j$ th data value of the time series, $\mathrm{n}$ is the number of data samples, and Sgn is a step function calculated by the formula (5).

$\mathrm{Z}$ values can calculate by formula (6):

$$
Z= \begin{cases}\frac{S-1}{\sqrt{\operatorname{VAR}(S)}}, & S>0 \\ 0, \quad S=0 & \\ \frac{S+1}{\sqrt{\operatorname{VAR}(S)}}, & S<0\end{cases}
$$



combination of $\mathrm{Z}$ value and Sen slope is shown in Table 3.

Table 3 meaning of Sen-Mann-Kendall test results

\begin{tabular}{|c|c|c|}
\hline $\begin{array}{c}\text { Trend } \\
\text { analysis }\end{array}$ & Sen $>0$ & Sen $<0$ \\
\hline$|Z|>1.96$ & Significant increase (S-increase) & Significant decrease (S-decrease) \\
\hline$|Z|<1.96$ & $\begin{array}{c}\text { Non-Significant increase (NS- } \\
\text { increase) }\end{array}$ & $\begin{array}{c}\text { Non-Significant decrease (NS- } \\
\text { decrease) }\end{array}$ \\
\hline
\end{tabular}

Hurst exponent is an index to describe the self-similarity and long-dependence of

Previous studies have shown that the Hurst exponent based on the rescaled range (R/S)

152 is more stable than other methods[17]. Therefore, we select the Hurst exponent to analyze the NDVI trend's continuity from 2000 to 2020.

$\Delta \mathrm{NDVI}_{i}=\mathrm{NDVI}_{i}-\mathrm{NDVI}_{i-1}$

$(m=1,2, \mathrm{~L}, n)$

158 (3) Cumulative deviation

$X(t)=\sum_{i=1}^{m}\left(\Delta \mathrm{NDVI}_{i}-\overline{\Delta \mathrm{NDVI}(m)}\right)$

$(1,, t, m)$ 


$$
\begin{aligned}
& R(m)=\max _{1, m, n} X(t)-\min _{1, m, n} X(t) \\
& (m=1,2, \mathrm{~L}, n)
\end{aligned}
$$

$$
\begin{aligned}
& S(m)=\left[\frac{1}{m} \sum_{i=1}^{m}\left(\Delta \mathrm{NDVI}_{i}-\overline{\Delta \mathrm{NDVI}(m)}\right)^{2}\right]^{\frac{1}{2}} \\
& (m=1,2, \mathrm{~L}, n)
\end{aligned}
$$
the continuity, and the larger the continuity.

Table 4 Meaning of Hurst exponent

\begin{tabular}{cccc}
\hline Hurst Range & $0<\mathrm{H}<0.5$ & 0.5 & $0.5<\mathrm{H}<1$ \\
\hline continuity & Anti-continuity Sequence & Random Sequence & continuity \\
\hline
\end{tabular}

164

\section{Results}

\subsection{NDVI trend in Rennell Island}

The Sen+Mann-Kendall analysis method was selected to obtain the distribution results for the changing trend of NDVI in Rennell Island from 2000 to 2020 (Fig. 3). It can be seen that the overall change trend of Rennell Island is not significant, and the mean Sen trend is $-0.1 \times 10^{-4}$. The ascending area accounted for $50 \%$ from the changing trend, and the descending area accounted for $49.9 \%$ of the total study area. From the Mann-Kendall test results, the significant change area accounted for 5.7\%, and the nonsignificant change area accounted for $94.1 \%$. The slightly degraded area accounted for $47.1 \%$ of the total study area, and the slightly improved area accounted for $47 \%$ of the whole study area. A slight degradation dominates the overall change of West Rennell where degradation occurs are in or near human settlements, which indicates that human 
activities likely have a significant impact on the disturbance of vegetation, especially through mining, deforestation, construction, and other disruptive activities on the island.

The overall change of East Rennell Island is slightly improved. The degenerated area is largely distributing to Lake Tengano and the inner periphery of the lake, which is more evident and continuous, mainly along some facilities and constructed structures along the lake.

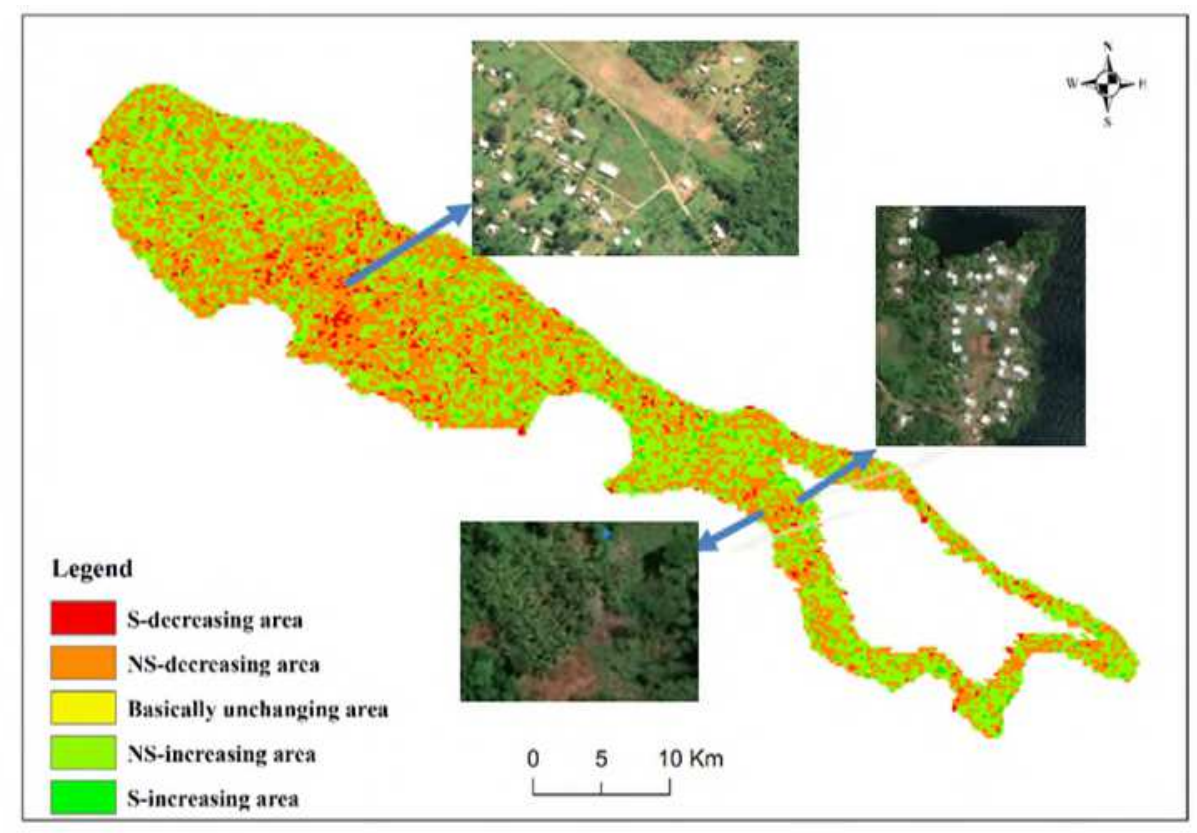

Figure 3 NDVI Trend of Rennell Island from 2000 to 2020

\subsection{NDVI future trend forecast for Rennell Island}

We used the Hurst exponent formula to obtain the distribution of persistent characteristics reflecting NDVI changes in Rennell Island from 2000 to 2020 (Fig. 4).

From the calculation results, Hurst values ranged from 0.097 to 0.725 , with a mean of 0.403. Hurst values were classified into Anti-Continuity $(\mathrm{AC})(\mathrm{H}<0.5)$, Moderate Continuity $(\mathrm{MC})(0.5<\mathrm{H}<0.65)$ and Highly Continuity $(\mathrm{HC})(\mathrm{H}>0.65)$. The anti- 
193

194

195

continuity of NDVI in Rennell Island is strong, and the anti-continuity area accounts for $86.5 \%$ of the study area. The overall anti-continuity characteristics indicate that Rennell Island's vegetation ecological environment is unstable, which means that the disturbance from the outside is frequent from 2000 to 2020, and further ecological restoration efforts need to be strengthened to ensure that the vegetation system will be improved. Both East and West of Rennell Islands are dominated by anti-continuity, and there is no significant feature from the continuity distribution perspective. To further analyze the change trend and persistence of vegetation in Rennell Island, Sen-Trend calculation result and Hurst index were superimposed for analysis (Fig. 5), which were divided into nine cases. The overlay results show that in the future, the changes in NDVI in most areas of Rennell Island will be unsustainable if the previous trend continues. The areas with persistent improvement and anti-continuity decrease of NDVI account for $6.5 \%$ and $43 \%$ of the total area, respectively, and are mainly located in the southwestern part of the island where the vegetation is likely to improve in the future.

The areas with an unchanged NDVI only account for $0.1 \%$, showing anti-continuity, and the future vegetation change trend depends on external disturbance. NDVI degradation in the northwest and southeast of Rennell Island presents $7 \%$ continuity and $43.4 \%$, improvement continuity anti-persistence. The results suggest that the future vegetation along the inner side of the lake of East Rennell Island may face degradation. 


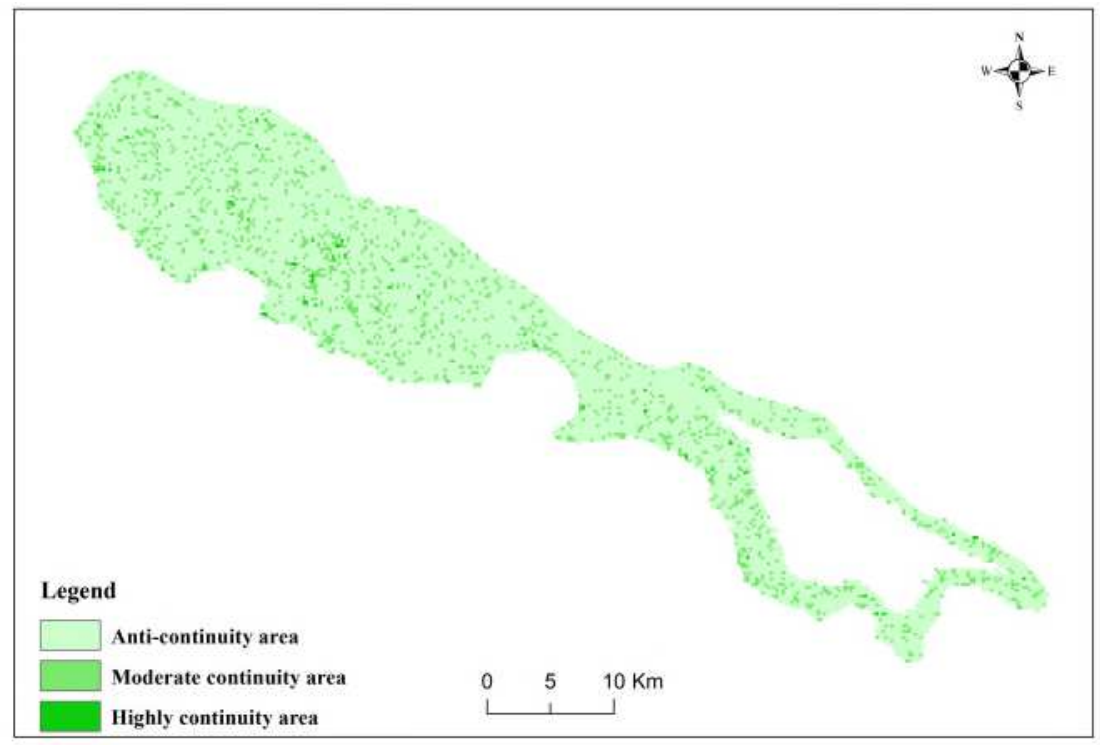

213 Figure 4 Hurst exponential spatial distribution of Rennell Island from 2000 to 2020

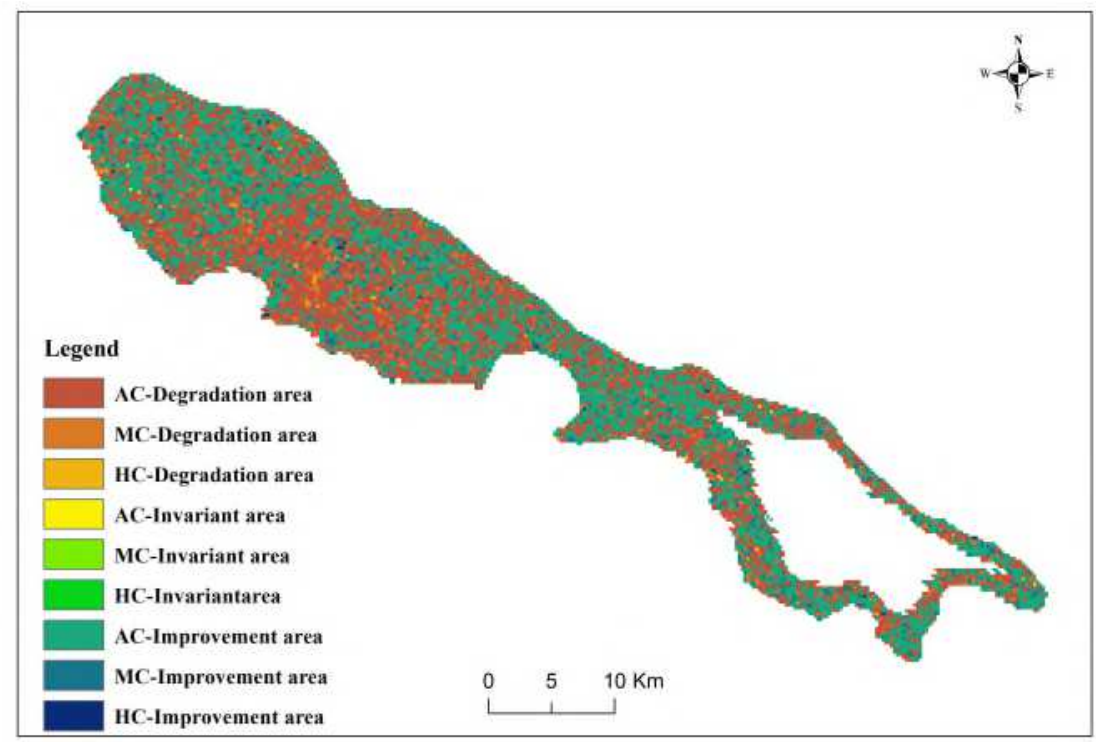

215 Figure 5 Continuity distribution of vegetation change in Rennell Island from 2000 to

Table 5 Monitoring of vegetation change in Rennell from 2000 to 2020

\begin{tabular}{|c|c|c|c|c|c|}
\hline \multicolumn{2}{|c|}{ Detection of Vegetation Change in Heritage Sites from 2000 } & \multicolumn{2}{c|}{ Future Trend Forecast } \\
\hline to 2020 & & $\begin{array}{c}\text { AC-Degeneration } \\
\text { area }\end{array}$ & $\begin{array}{c}43.0 \\
\%\end{array}$ \\
\cline { 1 - 3 } S-decreasing area & $2.9 \%$ & Degeneration & $50.0 \%$ & $\begin{array}{c}\text { MC-Degeneration } \\
\text { area }\end{array}$ & $6.7 \%$ \\
\hline NS-decreasing area & $47.1 \%$ & & & \begin{tabular}{c}
5 \\
\cline { 5 - 6 }
\end{tabular} &
\end{tabular}




\begin{tabular}{|c|c|c|c|c|c|}
\hline & & & & $\begin{array}{c}\text { HC-Degeneration } \\
\text { area }\end{array}$ & $0.3 \%$ \\
\hline \multirow{3}{*}{ Unchanging area } & \multirow{3}{*}{$0.1 \%$} & \multirow{3}{*}{ Unchanged } & \multirow{3}{*}{$0.1 \%$} & AC-Invariant area & $0.1 \%$ \\
\hline & & & & MC-Invariant area & $0.0 \%$ \\
\hline & & & & HC-Invariant area & $0.0 \%$ \\
\hline \multirow{2}{*}{ NS-increasing area } & \multirow{2}{*}{$47.0 \%$} & \multirow{3}{*}{ Improvement } & \multirow{3}{*}{$49.9 \%$} & $\begin{array}{c}\text { AC-Improvement } \\
\text { area }\end{array}$ & $\begin{array}{c}43.4 \\
\% \\
\end{array}$ \\
\hline & & & & $\begin{array}{c}\text { MC-Improvement } \\
\text { area }\end{array}$ & $6.3 \%$ \\
\hline S-increasing area & $2.9 \%$ & & & $\begin{array}{l}\text { HC-Improvement } \\
\text { area }\end{array}$ & $0.2 \%$ \\
\hline
\end{tabular}

\subsection{Forest/vegetation cover change in Rennell Island}

Due to data acquisition time and data quality constraints, fewer images per year were available on Rennell Island between 2012 and 2018. Data from the Landsat series with a spatial resolution of $30 \mathrm{~m}$ were used to extract and calculate the spatial distribution of forest/vegetation cover change (Fig. 6) and change (Fig. 7) in Rennell Island from 2012 to 2018. The red, yellow, and dark green patches in Figure 6 show the forest vegetation cover changes caused by agriculture, village and infrastructure construction, deforestation, mining activities, typhoons, and other natural disasters.

Disturbance to forest cover within the ERWHS was much less than outside of the site; disturbances within the ERWHS at higher elevations along the periphery of the Island were probably due to storms and other natural causes; disturbances closer to Lake Tengano were most likely due to use of forests by communities to meet their essential day-to-day needs; The Solomon Government considers that felling and mining concessions are restricted to residents' activity, but the Yellow patches (roads) significant changes, suggest that road construction for timber transport is likely to be the most significant factor in forest vegetation deterioration. The red patches in Fig. 6 
234 are traces of slash-and-burn agriculture, and the location and extent of the red area 235 changed year by year from 2012 to 2018 as the land after forest reclamation was used 236 for three years of agriculture, following which it then went into a fallow period for land 237 restoration. Lead cypress makes vegetation recovery fast, but it is necessary to recover 238 to the same forest communities as before. It takes a long time, maybe decades. 

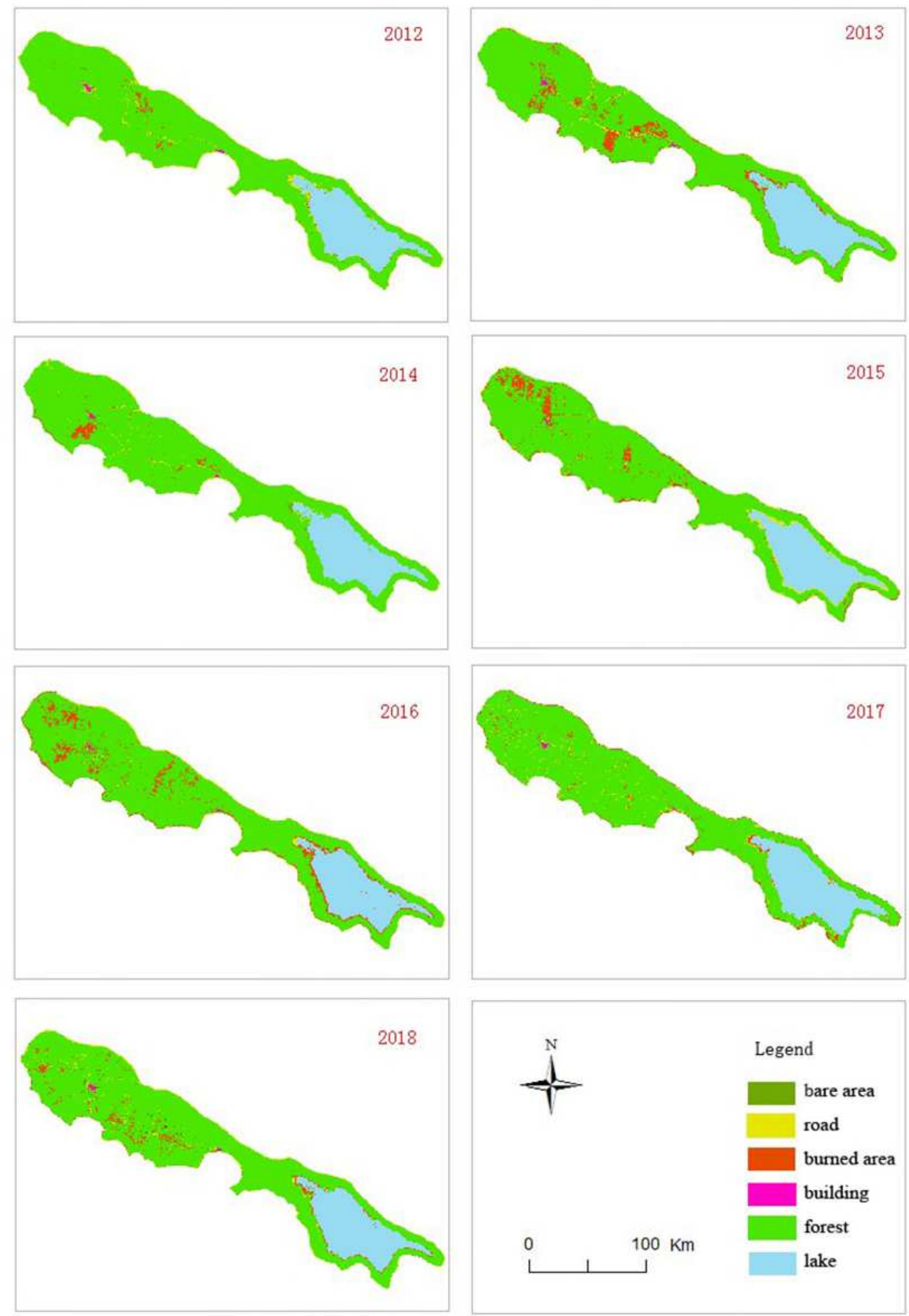

Figure 6 Changes in forest cover from 2012 to 2018

From the above analysis, it can be concluded that the areas with the most intense vegetation change are in the northwest part of the island, which is the well-known living 
244 living needs. The whole island is a natural ecosystem, and vegetation cover changes in

245 the West of Rennell islands inevitably affect the island's environment.

March 2014 to 3 October 2015 (Fig. 7 and Fig. 8).

\subsection{Land cover classification based on Worldview image}

To further analyze Rennell Island's land cover, a detailed classification of land cover in the study area was done using 20 image mosaics of the entire island from 19

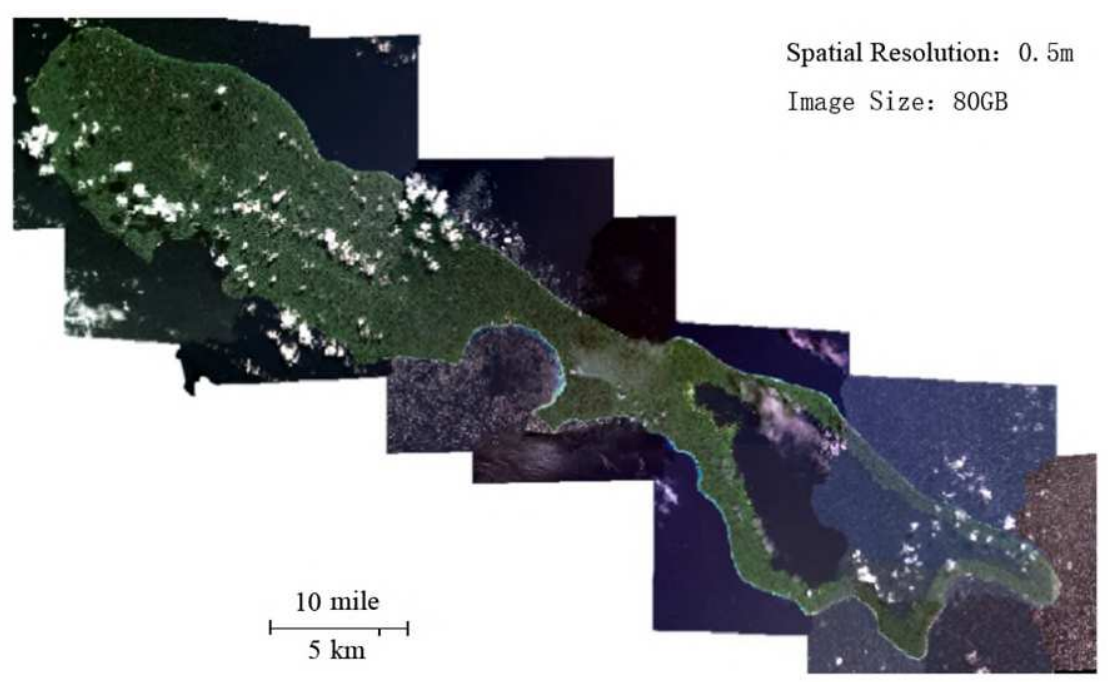

Figure 7 Worldview image covering the Rennell Island

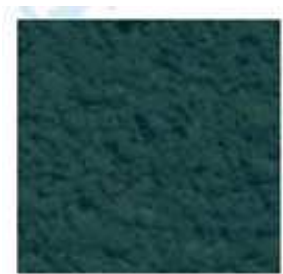

Unspoiled forest

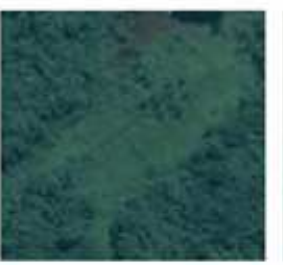

Farmland

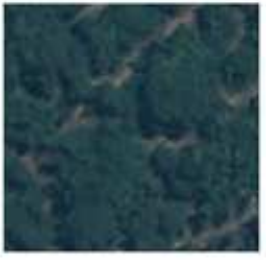

Un-reclaimed forest

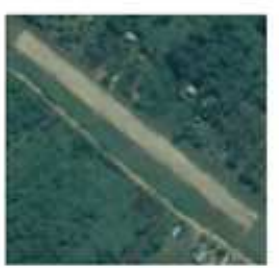

Airport

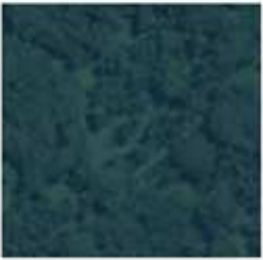

Reclaimed forest

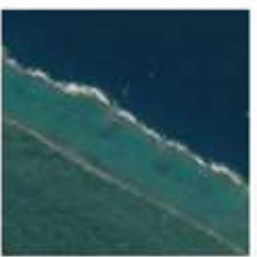

coast

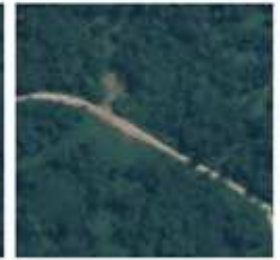

Road

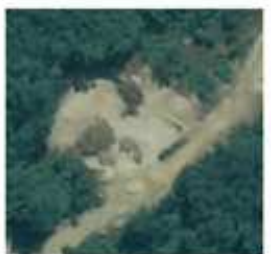

Bare land

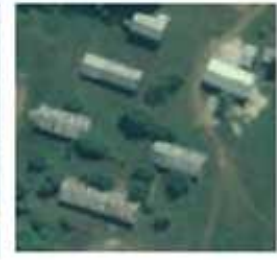

Building

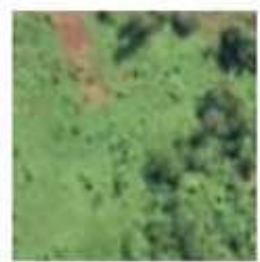

Grass Land

Figure 8 Categories of the land cover classification system 

percentage of virgin forests on the island is still over 90\%. East Rennell Island's original forest area accounts for $52 \%$, considering that Lake Tengano accounts for $44.73 \%$ of the total area. Moreover, the original forest area accounts for more than $95 \%$ of the land area. As a result, $93 \%$ of the land area is primitive forest (see Table 6). areas in Landsat series images. Comprehensive comparative analysis using highresolution Worldview and Landsat 8 data shows that the proportion of land with high vegetation coverage and high vegetation coverage is significantly greater than that under low vegetation types (Table 6). The data of land cover type in 2014 is consistent with the results of annual monitoring data of Landsat 8 , which verifies that the vegetation cover of Rennell Island is restored to the maximum extent in the second year

following it enlisting as an endangered heritage site.

Table 6 Percentage for West, East (ERWHS) and the whole of the Rennell Island

\begin{tabular}{|c|c|c|c|c|c|c|}
\hline & \multicolumn{2}{|c|}{ West of Rennell Island } & \multicolumn{2}{c|}{$\begin{array}{c}\text { East of Rennell } \\
\text { Island }\end{array}$} & \multicolumn{2}{c|}{$\begin{array}{c}\text { Whole Rennell } \\
\text { Island }\end{array}$} \\
\hline Type & $\begin{array}{c}\text { Area } \\
\left(\mathrm{km}^{2}\right)\end{array}$ & $\begin{array}{c}\text { Percent } \\
(\%)\end{array}$ & $\begin{array}{c}\text { Area } \\
\left(\mathrm{km}^{2}\right)\end{array}$ & $\begin{array}{c}\text { Percent } \\
(\%)\end{array}$ & $\begin{array}{c}\text { Area } \\
\left(\mathrm{km}^{2}\right)\end{array}$ & $\begin{array}{c}\text { Percent } \\
(\%)\end{array}$ \\
\hline $\begin{array}{c}\text { Unspoiled } \\
\text { forest }\end{array}$ & 443.83 & 92.34 & 187.76 & 52.53 & 631.59 & 75.36 \\
\hline $\begin{array}{c}\text { Reclaimed } \\
\text { forest }\end{array}$ & 18.62 & 3.87 & 0 & 0 & 18.62 & 2.22 \\
\hline Farmland & 4.76 & 0.99 & 3.04 & 0.85 & 7.8 & 0.93 \\
\hline $\begin{array}{c}\text { Un- } \\
\text { reclaimed } \\
\text { forest }\end{array}$ & 3.84 & 0.8 & 0 & 0 & 3.84 & 0.46 \\
\hline Grassland & 0.16 & 0.03 & 0.05 & 0.02 & 0.21 & 0.03 \\
\hline Bare land & 0.73 & 0.15 & 0.1 & 0.03 & 0.84 & 0.10 \\
\hline Building & 0.07 & 0.02 & 0.03 & 0.01 & 0.11 & 0.01 \\
\hline Road & 1.11 & 0.23 & 0.11 & 0.03 & 1.22 & 0.15 \\
\hline
\end{tabular}




\begin{tabular}{|c|c|c|c|c|c|c|}
\hline Waterbody & 0 & 0 & 159.89 & 44.73 & 159.89 & 19.08 \\
\hline Coast & 7.47 & 1.55 & 6.5 & 1.82 & 13.96 & 1.67 \\
\hline Airport & 0.05 & 0.01 & 0 & 0 & 0.05 & 0.01 \\
\hline
\end{tabular}

\section{Discussion}

\subsection{Impact factors induced the vegetation varieties}

Forest/vegetation cover change are worth noting: the most intensive activities disturbing the forest cover occurred in the northern most parts of the island; Forests were opened up by local communities for slash-and-burn agriculture and for harvesting wood for local needs such as boat and housing construction; slash-and-burn agriculture is rare within the ERWHS. Some of the larger clearances during specific years were attributable to time-limited activities or events; For example, the large, but dispersed patches of clearing in the middle of the Island in 2001 were linked to port construction and associated development of settlements and villages; There was significant damage due to storms in 2003; and it was a very dry year and there was considerable burning of forests in 2007 . The analysis results from 2000 to 2020 show that: in this area are about $1: 1$, but the overall change trend is not significant and weak. The original forest cover is high, and the ability to recover after vegetation destruction is strong. Undisturbed or unspoiled forest areas in Rennell remain high and contiguous. activities. 
residents and natural disasters. Road construction has become the primary cause of forest vegetation destruction. The government is restricting mining activities in forest areas cleared by agriculture and will not develop new mining area[18].

\subsection{Suggestions}

Consideration must be given to the planning and management regarding sustainable connectivity and forest cover contiguity in key areas. The timing of the removal of ERWHS from the Danger List must also be considered in the context of facilitating the State Party and community interests to improve the state of conservation and livelihood and income-generating options that are compatible with conservation. While the removal of ERWHS from the Danger List is subject to the removal of all threats to the site[19], the time needed for achieving such complete elimination of all threats is likely to be quite long. For the State Party, it would be helpful if the site could be removed from the World Heritage in Danger List as soon as the plan and time-frame for the mitigation of all prevailing threats to the conservation of ERWHS and regular monitoring of the implementation of the plan by UNESCO and International Union for Conservation of Nature (IUCN) have been considered and approved by the World Heritage Committee.

According to the data analysis, we give the several suggestions as follows:

(1) A land cover classification comprising of 10 categories has been established (see Fig. 8) for the whole of Rennell Island based on high-resolution Worldview images (0.5-2m resolution) for 2014-2015. The World Heritage Centre and IUCN may use those satellite remote sensing data as the baseline for future forest cover monitoring of 
Rennell Island.

(2) Currently, there is no buffer zone demarcated for ERWHS. The demand for demarcating a buffer zone extending up to a specific distance from the current western boundary of the ERWHS further into western parts of the Island exists but will involve complex and challenging negotiations between the community owning land immediately outside the western boundary of ERWHS, communities resident within ERWHS and national and provincial Government authorities, respectively. A buffer zone where economic activities such as forestry and agriculture are prohibited will be difficult to achieve via negotiations. Furthermore, for the buffer zone to be established to ensure connectivity of forests between ERWHS and the western parts of the island, considerable new data on the distribution and population status of land-based avian and invertebrate endemics that occur within the ERWHS would be needed.

(3) A recent REDD Feasibility Study for ERWHS (SPC/GIZ, 2013) had noted: "While East Rennell has been a UNESCO World Heritage site for the last 14 years it does not have protected area status; and thus the decision to continue conserving the island or to log it is mostly in the hands of customary landowners. There have been at least two formal proposals to log East Rennell, with the latest presented in 2011/12 when a timber rights hearing was held in two villages. This report contends that without a forest carbon project, and facing declines in agricultural production and fish catches, the customary landowners will most likely be forced to allow logging of East Rennell to gain revenue for food and other stables."

The same report goes on to claim that: 

a forest carbon project could conservatively generate a total of 1.03 million tons of $\mathrm{CO}_{2}$ of avoided emissions over 10 years, which could generate total revenues of US\$ 3.1 million to 9.3 million.”

A UN REDD-linked avoided deforestation scheme, with potential financing via new and emerging global funding mechanisms such as the Global Climate Fund, could benefit the ERWHS and sustainable forestry practices outside the World Heritage site.

The Intended Nationally Determined Contributions (INDC) of Solomon Islands at the

21st session of the UN Framework Convention on Climate Change (UNFCCC) held in

Paris, France from 30 November to 11 December 2015 mentions the importance of land banning all logging in the property[21]. While this measure can serve as a temporary solution, in the longer term, it will be important to introduce a legal mechanism, such as an application to be submitted by the customary owners, to designate the property 
under the Protected Areas Act and adopt its Management Plan, which would protect the property from commercial logging. In 2018, the world's first insurance industry statement of commitment to protect World Heritage sites was launched. The statement was developed by UN Environment's Principles for Sustainable Insurance Initiative (PSI), WWF, and UNESCO's World Heritage Centre. An oil spill has reportedly occurred in East Rennell, Solomon Islands on Tuesday, 19 February 2017, when a bulk carrier ran aground at Kangava Bay, just outside of the World Heritage property[22]. In February 2019, an oil spill occurred near East Rennell[23].

Climate change, natural disasters, wars and many other factors threaten the world heritage sites. The 53 properties that the World Heritage Committee has decided to include on the List of World Heritage in danger according to Article 11 (4) of the Convention. The States Parties to the Convention should inform the Committee about threats to their sites as soon as possible. On the other hand, private individuals, nongovernmental organizations, or other groups may also draw the Committee's attention to existing threats[24]. If the alert is justified and the problem serious enough, the Committee may consider including the site on the List of World Heritage in Danger. The core word of world heritage is "outstanding universal value," and its constituent elements meet the standards of the world heritage, the authenticity and integrity verification, and the effective protection and management mechanism [22]. Space technologies can macroscopically, quickly and accurately identify the features and status of ground objects. Satellite navigation and positioning technology can accurately locate, and geographic information technology can quickly and effectively perform the 
377

spatial analysis. These cutting-edge spatial information technologies have proven the advantages of space archaeology and heritage protection. Furthermore, Space technologies play a role in the detection and protection of large cultural heritage such as the Silk Road in the future.

\section{List of Abbreviations}

\begin{tabular}{cc}
\hline Full name & Abbreviations \\
\hline Hectare (ha) & ha \\
United Nations Educational, Scientific and Cultural & \\
Organization (UNESCO)" & UNESCO \\
"kilometers (km)" & $\mathrm{km}$ \\
"Normalized Difference Vegetation Index (NDVI)" & NDVI \\
"International Union for Conservation of Nature & \\
(ICUN)" & ICUN \\
Moderate-resolution Imaging Spectroradiometer & MODIS \\
\hline
\end{tabular}

\section{Declarations}

\section{Availability of data and materials}

The authors confirm that data supporting the finding of this study are available.

MODIS Vegetation Indices 16-Day L3 Global 250m database come from Earth Science Data Systems (ESDS) Program of National Aeronautics and Space Administration (NASA).https://search.earthdata.nasa.gov/search?q=MOD13Q1. Landsat 8 image dataset come from NASA. https://glovis.usgs.gov/ Worldview image data come from HIST. 


\section{Competing interests}

The authors declare no conflict of interest.

\section{Funding}

This research was funded by the Netherland Funds-in-Trust (NFiT) at the World Heritage of UNESCO and Sub project of Earth Big Data Science and Engineering of Chinese Academy of Sciences Pilot Project (XDA19030501).

\section{Author Contributions}

Conceptualization, Sijia Huo; methodology, Mengmeng Wang and Guolong Chen; software, Huiqin Shu and Ruixia Yang ; validation, Guolong Chen.; formal analysis, Mengmeng Wang and Guolong Chen ; writing_original draft preparation , Sijia Huo; writing-review and editing, Sijia Huo and Guolong Chen; All authors have read and agreed to the published version of the manuscript.

\section{Acknowledgments}

We sincerely acknowledge the constructive comments and suggestions given by Prof.

Fu Bihong from HIST that greatly helped to improve the manuscript.

\section{Authors' information}

1 International Centre on Space Technologies for Natural and Cultural Heritage,

The Aerospace Information Research Institute, Chinese Academy of Sciences, Beijing 100094, China;

2 University of Chinese Academy of Sciences, Beijing 100049, China;

3 China University of Geosciences, Wuhan 430072, China

\section{References}


412

413

1. Levin N, Ali S, Crandall D, Kark S. World Heritage in danger: Big data and remote sensing can help protect sites in conflict zones. Global Environmental Change. 2019;55:97-104.

2. Pałaś KW, Zawadzki J. Sentinel-2 imagery processing for tree logging observations on the białowieża forest world heritage site. Forests. 2020;11(8):857.

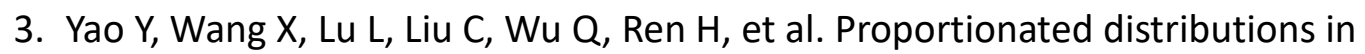
spatiotemporal structure of the world cultural heritage sites: Analysis and countermeasures. Sustainability-Basel. 2021;13(4):2148.

4. World Heritage Site website: https://whc.unesco.org/en/danger/. Accessed April 202021.

5. Wang M, He G, Ishwaran N, Hong T, Bell A, Zhang Z, et al. Monitoring vegetation dynamics in East Rennell Island World Heritage Site using multi-sensor and multitemporal remote sensing data. Int J Digit Earth. 2018;13(3):393-409.

6. World Heritage Site website: http://whc.unesco.org/en/list/854/. Accessed April 202021.

7. Shiels AB, Pitt WC, Sugihara RT, Witmer GW. Biology and Impacts of Pacific Island Invasive Species. 11. Rattus rattus, the Black Rat (Rodentia: Muridae) . Pacific Science. 2014;2(68):145-184.

8. Loveridge R, Wearn OR, Vieira M, Bernard H, Ewers RM. Movement behavior of native and invasive small mammals shows logging may facilitate invasion in a tropical rain forest. Biotropica. 2016;48(3):373-380.

9. Chen F, Guo H, Ma P, Lin H, Wang C, Ishwaran N, et al. Radar interferometry 
offers new insights into threats to the Angkor site. Sci Adv. 2017;3(3):e1601284.

10. Erasmi S, Klinge M, Dulamsuren C, Schneider F, Hauck M. Modelling the productivity of Siberian larch forests from Landsat NDVI time series in fragmented forest stands of the Mongolian forest-steppe. Environ Monit Assess. $2021 ; 193(4)$

11. Fernández-Guisuraga JM, Calvo L, Suárez-Seoane S. Comparison of pixel unmixing models in the evaluation of post-fire forest resilience based on temporal series of satellite imagery at moderate and very high spatial resolution. Isprs J Photogramm. 2020;164:217-228.

12. SPC/GIZ. 2013. REDD Feasibility Study for East Rennell World Heritage Site, Solomon Islands. A joint study conducted by the Secretariat of the Pacific Community (SPC) and the German Technical Agency GIZ. SPC/GIZ Regional REDD Project, Suva, Fiji. 41 pages including annexes.

13. Liu Q, Wang X, Zhang Y, Zhang H, Li L. Vegetation Degradation and its Driving Factors in the Farming-Pastoral Ecotone over the Countries along Belt and Road Initiative. Sustainability-Basel. 2019;11(6):1590.

14. Wang Y, Liu X, Ren G, Yang G, Feng Y. Analysis of the spatiotemporal variability of droughts and the effects of drought on potato production in northern China. Agr Forest Meteorol. 2019;264:334-342.

15. Jovanovic D, Jovanovic T, Mejía A, Hathaway J, Daly E. Technical note: Long-term persistence loss of urban streams as a metric for catchment classification. Hydrol Earth Syst Sc. 2018;22(6):3551-3559. 
16. Na L, Na R, Zhang J, Tong S, Shan Y, Ying H, et al. Vegetation dynamics and diverse responses to extreme climate events in different vegetation types of inner mongolia. Atmosphere-Basel. 2018;9(10):394.

17. Hott MC, Carvalho LMT, Antunes MAH, Resende JC, Rocha WSD. Analysis of grassland degradation in zona da mata, MG, brazil, based on NDVI time series data with the integration of phenological metrics. Remote Sens-Basel. 2019;11(24):2956.

18. Grech A, Pressey RL, Day JC. Coal, cumulative impacts, and the great barrier reef. John Wiley \& Sons, Ltd (10.1111). 2016;200-208(9).

19. UN-REDD Programme: http://www.un-redd.org/, Accessed April 202021.

20. Furusawa $T$, Sirikolo MQ, Sasaoka M, Ohtsuka R. Interaction between forest biodiversity and people's use of forest resources in Roviana, Solomon Islands: Implications for biocultural conservation under socioeconomic changes. J Ethnobiol Ethnomed. 2014;10:10.

21. World Heritage Site website: http://whc.unesco.org/en/news/1719/. Accessed April 202021.

22 World Heritage Site website: http://whc.unesco.org/en/news/1934/. Accessed April 202021.

23 World Heritage Site website: http://whc.unesco.org/en/news/1948/. Accessed April 202021.

24. Dingwall. P. Report on the Reactive Monitoring Mission to East Rennell, Solomon Islands, IUCN Gland.2013. https://whc.unesco.org/en/documents/122248/. 
Accessed April 212021.

479

480 


\section{Figures}

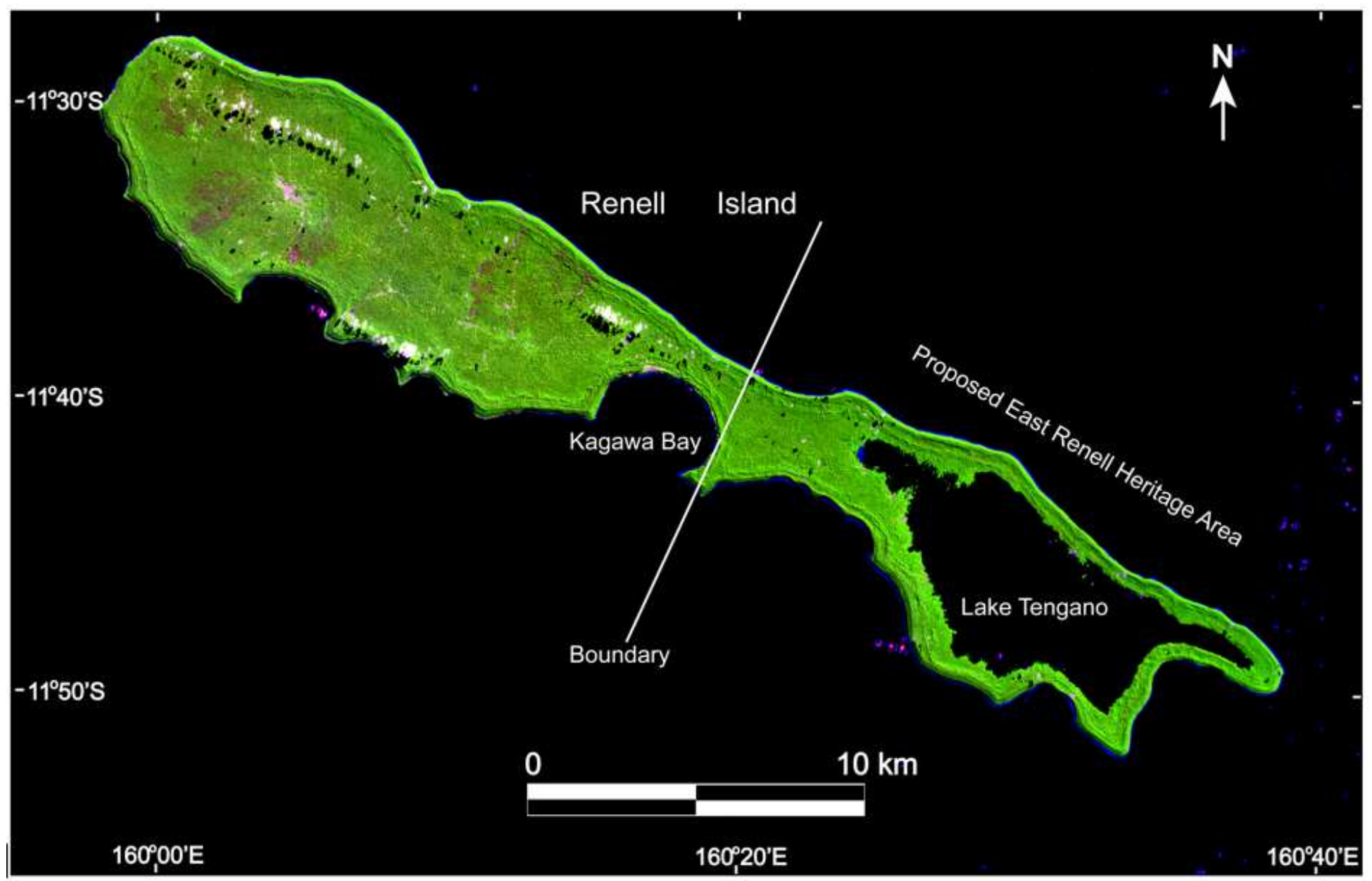

\section{Figure 1}

Landsat 8 image of Rennell Island showing the vegetation coverage of East Rennell heritage site on June 07, 2016 Note: The designations employed and the presentation of the material on this map do not imply the expression of any opinion whatsoever on the part of Research Square concerning the legal status of any country, territory, city or area or of its authorities, or concerning the delimitation of its frontiers or boundaries. This map has been provided by the authors. 

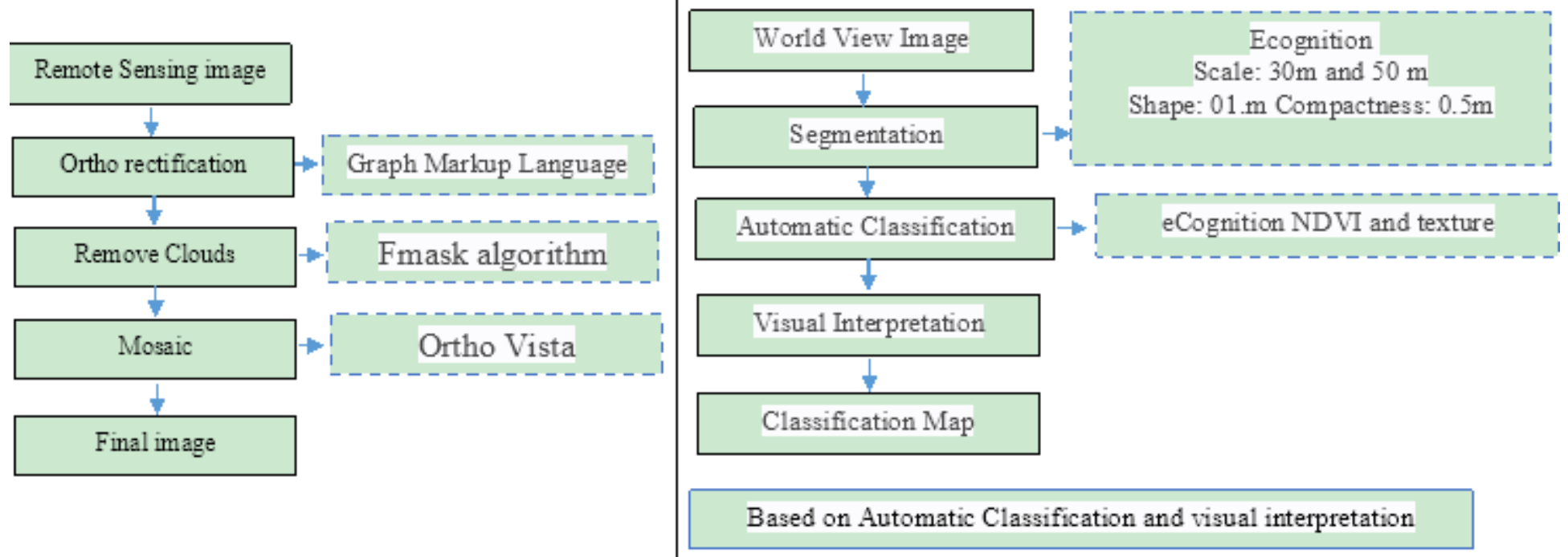

\section{Figure 2}

Flow chart for processing of the preprocessed data

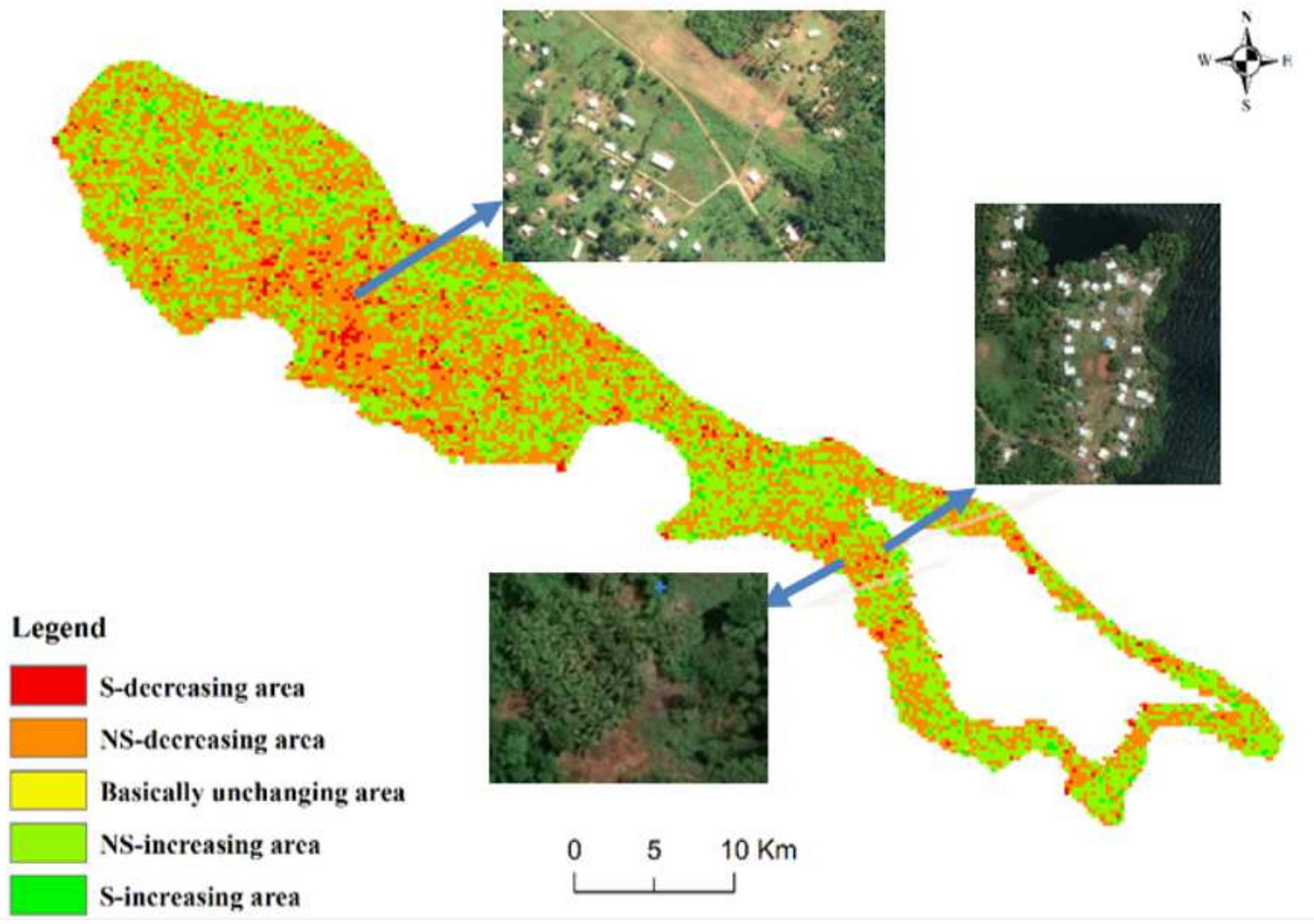


NDVI Trend of Rennell Island from 2000 to 2020 Note: The designations employed and the presentation of the material on this map do not imply the expression of any opinion whatsoever on the part of Research Square concerning the legal status of any country, territory, city or area or of its authorities, or concerning the delimitation of its frontiers or boundaries. This map has been provided by the authors.

Legend

Anti-continuity area

Moderate continuity area

Highly continuity area

\section{Figure 4}

Hurst exponential spatial distribution of Rennell Island from 2000 to 2020 Note: The designations employed and the presentation of the material on this map do not imply the expression of any opinion whatsoever on the part of Research Square concerning the legal status of any country, territory, city or area or of its authorities, or concerning the delimitation of its frontiers or boundaries. This map has been provided by the authors. 


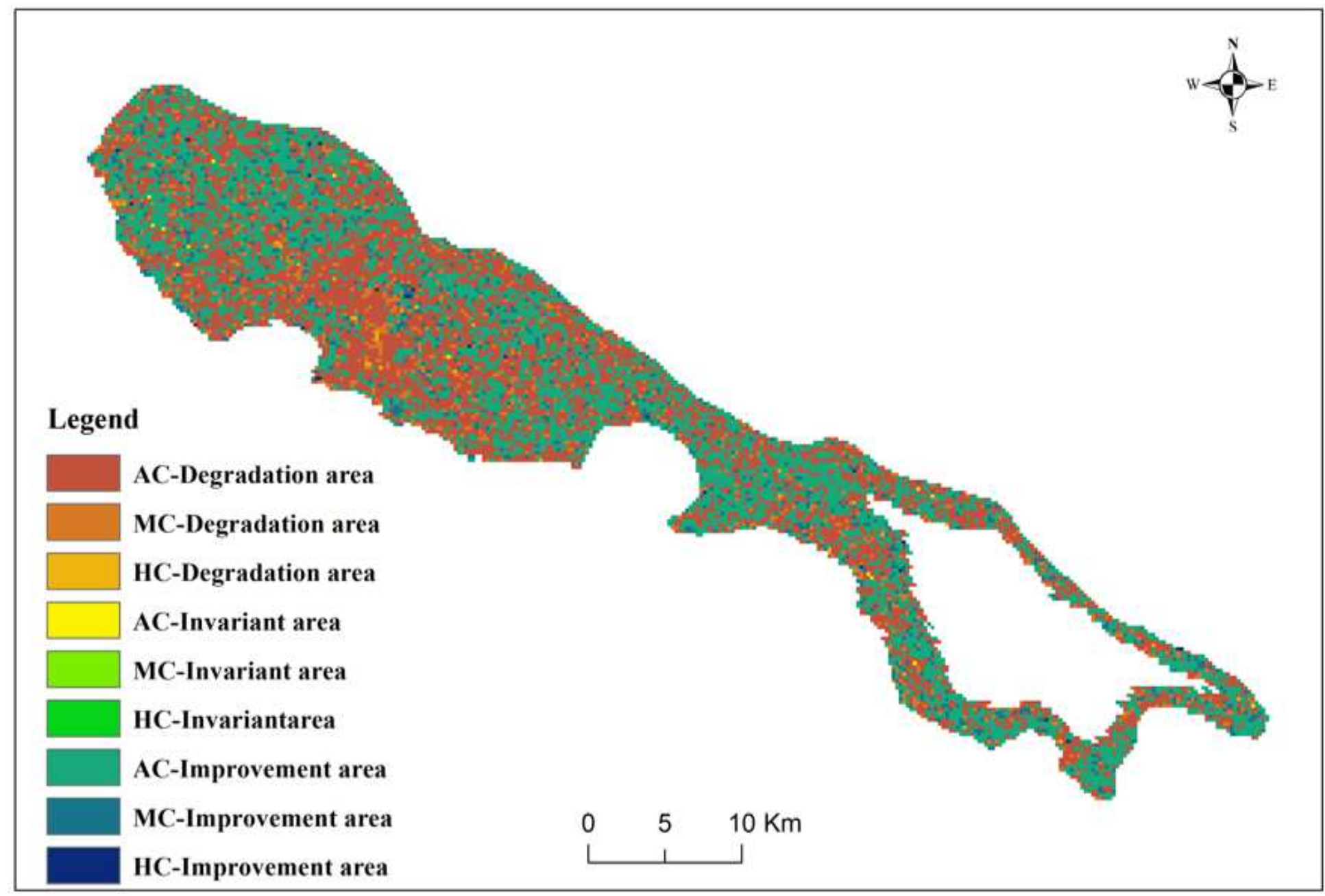

Figure 5

Continuity distribution of vegetation change in Rennell Island from 2000 to 2020 Note: The designations employed and the presentation of the material on this map do not imply the expression of any opinion whatsoever on the part of Research Square concerning the legal status of any country, territory, city or area or of its authorities, or concerning the delimitation of its frontiers or boundaries. This map has been provided by the authors. 

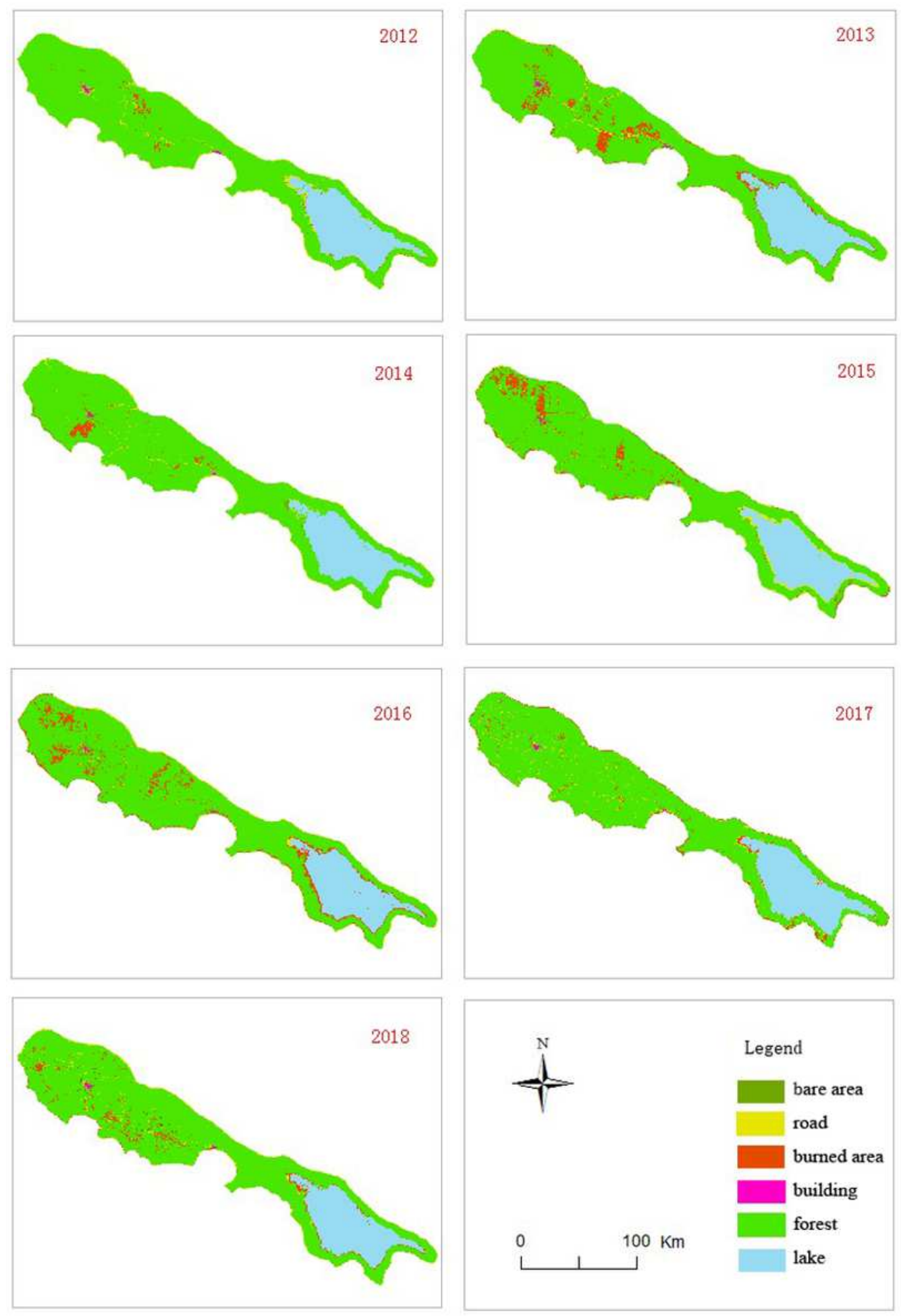

\section{Figure 6}

Changes in forest cover from 2012 to 2018 Note: The designations employed and the presentation of the material on this map do not imply the expression of any opinion whatsoever on the part of Research Square concerning the legal status of any country, territory, city or area or of its authorities, or concerning the delimitation of its frontiers or boundaries. This map has been provided by the authors. 


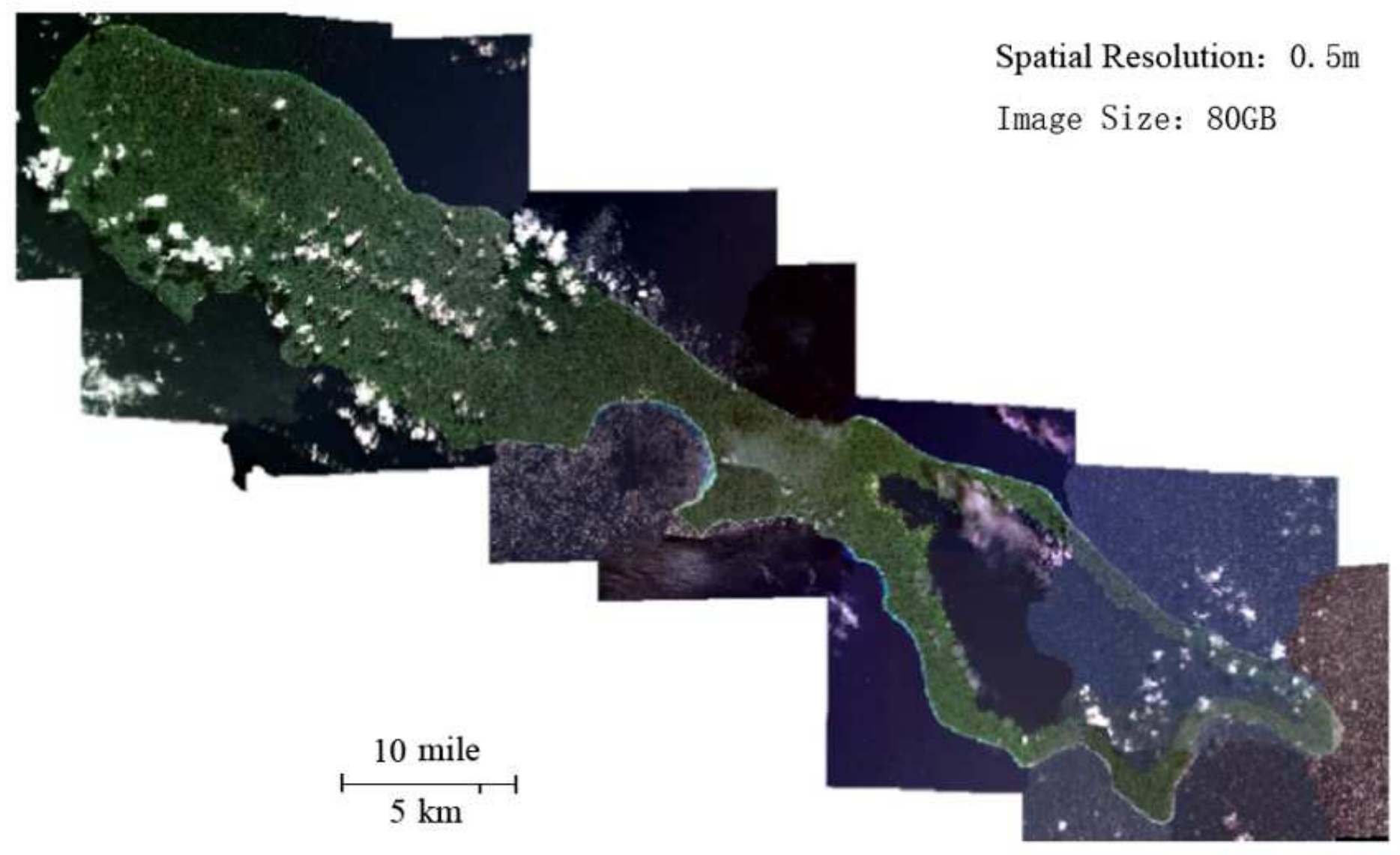

Figure 7

Worldview image covering the Rennell Island Note: The designations employed and the presentation of the material on this map do not imply the expression of any opinion whatsoever on the part of Research Square concerning the legal status of any country, territory, city or area or of its authorities, or concerning the delimitation of its frontiers or boundaries. This map has been provided by the authors. 


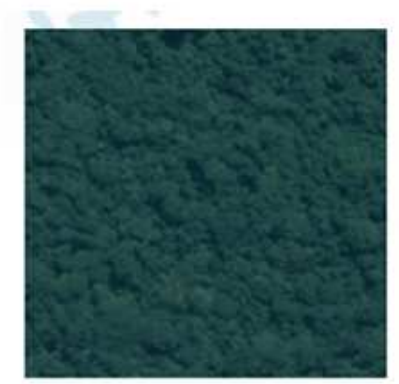

Unspoiled forest

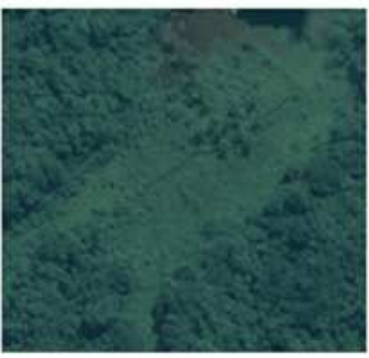

Farmland

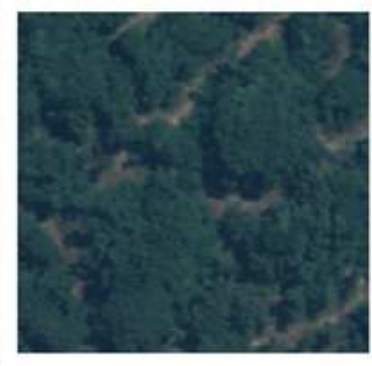

Un-reclaimed forest

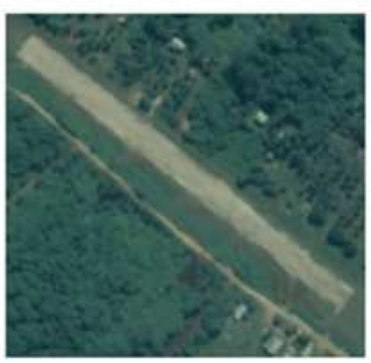

Airport

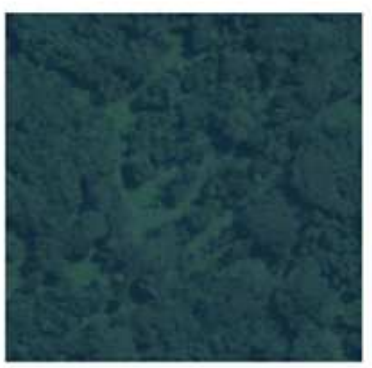

Reclaimed forest

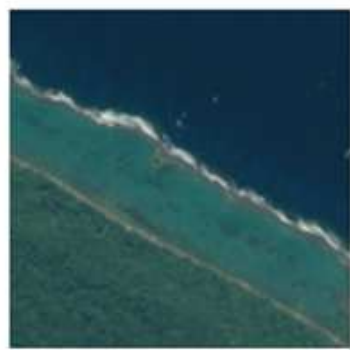

coast

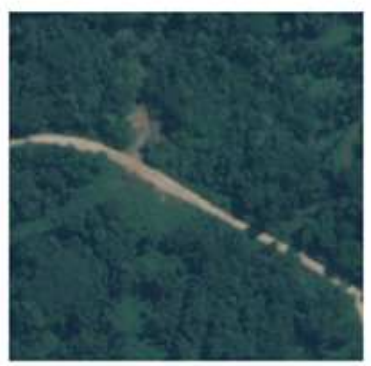

Road

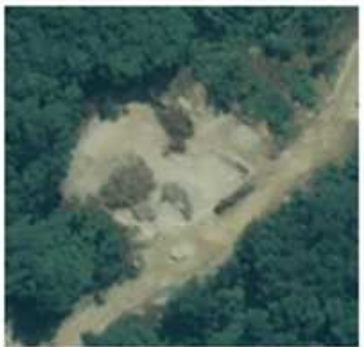

Bare land

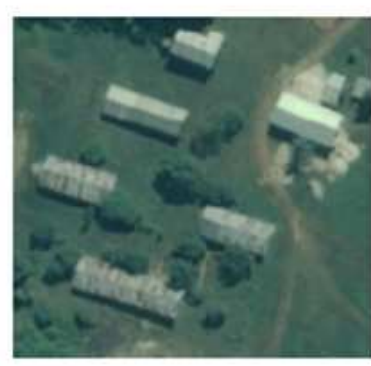

Building

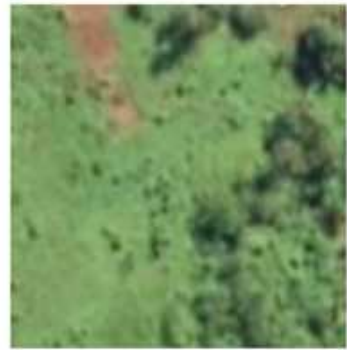

Grass Land

\section{Figure 8}

Categories of the land cover classification system Note: The designations employed and the presentation of the material on this map do not imply the expression of any opinion whatsoever on the part of Research Square concerning the legal status of any country, territory, city or area or of its authorities, or concerning the delimitation of its frontiers or boundaries. This map has been provided by the authors.

\section{Supplementary Files}

This is a list of supplementary files associated with this preprint. Click to download.

- TablesinPaper.rar

- figuresinpaper.rar 